\title{
Physiological characteristics of dairy cows producing milk of high or low protein concentration
}

\author{
I. Bruckental, M. Kaim, I. Silanikov and H. Tagari \\ Institute of Animal Sciences, Agricultural Research Organization, Volcani Center, PO Box 6, Bet Dagan 50250, Israel
}

\section{Introduction}

The need for a better understanding of the nutritional and physiological factors underlying milk protein synthesis and secretion, is stimulated by the increasing demand for milk protein. The possibilities available for producers to increase milk protein concentration are very limited. The physiologicalbiochemical mechanism which is involved in controlling the level of milk protein is not yet fully understood. Heritability of milk protein concentration is very high. The average milk protein concentration in the Israeli dairy herd, during 1993, was $29.9 \mathrm{~g} / \mathrm{kg}$. The heritability of protein concentration in the Israeli dairy herd is 0.46 , and its standard deviation is very small (Ezra, Raz and Weller, 1988). This means that in the short term, relatively little progress can be achieved. Genetic differences for studying biological processes are widely used in plants, less so in animals and hardly in ruminants. Oldham, Simm and Marsden (1992) described several studies in this area. If milk protein concentration is of high heritability, cows constantly producing milk of high (HP) or low (LP) protein concentration can be singled out. Milk protein excretion is the final stage that food protein undergoes through body metabolism. Differences between cows in the utilization efficiency of food protein for milk protein can be expressed through the concentration of metabolites in the digestive tract and body fluids.

\section{Material and methods}

In a survey carried out in two commercial herds (I and II), cows producing milk of below and above average protein concentration per lactation, higher than $32 \mathrm{~g} / \mathrm{kg}$ or lower than $28 \mathrm{~g} / \mathrm{kg}$, were singled out (Table 1). It was assumed that a difference greater than proportionately 0.10 in protein concentration is large enough to affect physiologicalbiochemical processes. Rumen fluid and blood samples were taken from the cows after morning milking and prior to their morning meal. In both herds all the cows were given the same mixed ration.

A similar comparison was carried out in two other commercial herds (farms III and IV) in which the reproductive management was controlled and recorded by a research team from the Department of Reproduction, Volcani Center, during the years 19891993. No data were taken from the summer calving cows whose fertility is affected by the high environmental temperatures.

\section{Results}

In herds I and II, the rumen fluid $\mathrm{pH}$ tended to be higher in the HP cows compared with the LP cows (Table 2). The rumen fluid ammonia was similar in the HP and LP cows in both herds, but the blood urea level was significantly lower in the HP cows. The reproductive data of both herds were taken as recorded by the local veterinarian. The number of

Table 1 Average performance of cows low $(<28 \mathrm{~g} / \mathrm{kg})$ and high $(>32 \mathrm{~g} / \mathrm{kg})$ in milk crude protein (CP) concentration, during the lactation prior to the test

\begin{tabular}{|c|c|c|c|c|c|c|c|}
\hline & $\begin{array}{c}\text { Milk CP } \\
(\mathrm{g} / \mathrm{kg})\end{array}$ & No. & $\begin{array}{c}\text { Solids-corrected } \\
\text { milk } \\
\text { (kg per } \\
\text { lactation) }\end{array}$ & $\begin{array}{c}\text { Milk } \\
\text { fat } \\
\text { (g/kg) }\end{array}$ & $\begin{array}{c}\text { Milk } \\
\text { CP } \\
(\mathrm{g} / \mathrm{kg})\end{array}$ & $\begin{array}{c}\text { Milk fat } \\
\text { (kg per } \\
\text { lactation) }\end{array}$ & $\begin{array}{c}\text { Milk CP } \\
\text { (kg per } \\
\text { lactation) }\end{array}$ \\
\hline \multirow[t]{2}{*}{ Farm I } & $<28$ & 39 & 10933 & $2 \cdot 89^{b}$ & $2 \cdot 83^{b}$ & $325^{a b}$ & $315^{\mathrm{ab}}$ \\
\hline & $>32$ & 38 & 9765 & $3 \cdot 32^{a}$ & $3 \cdot 31^{\mathrm{a}}$ & $309^{b}$ & $321^{\mathrm{ab}}$ \\
\hline \multirow[t]{2}{*}{ Farm II } & $<28$ & 20 & 10438 & $2.92^{b}$ & $2 \cdot 80^{b}$ & $308^{b}$ & $292^{b}$ \\
\hline & $<32$ & 22 & 10128 & $3.42^{\mathrm{a}}$ & $3 \cdot 27^{\mathrm{a}}$ & $346^{a}$ & $332^{a}$ \\
\hline
\end{tabular}

a,b Level of significance of differences indicated is $P<0.05$. 
Table 2 Average rumen fluid ammonia-nitrogen $\left(\mathrm{NH}_{3}-\mathrm{N}\right)$ and $\mathrm{pH}$, blood urea-N concentrations, and inseminations per conception of cows of farms I and II, low $(<28 \mathrm{~g} / \mathrm{kg})$ and high $(>32 \mathrm{~g} / \mathrm{kg})$ in milk protein concentration (number of animals in brackets)

\begin{tabular}{|c|c|c|c|c|c|}
\hline $\begin{array}{c}\text { Milk } \\
\text { Protein } \\
\text { level }(\mathrm{g} / \mathrm{kg})\end{array}$ & & $\begin{array}{l}\text { Rumen } \\
\mathrm{NH}_{3}-\mathrm{N} \\
(\mathrm{mg} / 1)\end{array}$ & $\begin{array}{l}\text { Blood } \\
\text { urea-N } \\
(\mathrm{mg} / 1)\end{array}$ & $\begin{array}{c}\text { Rumen } \\
\text { fluid } \\
\text { pH }\end{array}$ & $\begin{array}{c}\text { Inseminations } \\
\text { per } \\
\text { conception }\end{array}$ \\
\hline \multirow[t]{2}{*}{$<28$} & Heifers & & & & $1.44(25)$ \\
\hline & Cows & $110(23)$ & $233^{a}$ & $6 \cdot 71$ & $1.86(49)$ \\
\hline \multirow[t]{3}{*}{$>32$} & Heifers & & & & $2.00(26)$ \\
\hline & Cows & $100(32)$ & $184^{b}$ & 6.97 & $2 \cdot 18(55)$ \\
\hline & s.e. & $12 \cdot 6$ & $9 \cdot 6$ & $0 \cdot 11$ & 0.37 \\
\hline
\end{tabular}

Table 3 Average reproductive performance of cows of farms III and $I V, l o w(<28 \mathrm{~g} / \mathrm{kg})$ and high $(>32 \mathrm{~g} / \mathrm{kg})$ in milk protein concentration, during the years 1989-1993

\begin{tabular}{|c|c|c|c|c|c|c|}
\hline & \multicolumn{6}{|c|}{ Milk protein concentration $(\mathrm{g} / \mathrm{kg})$} \\
\hline & \multicolumn{3}{|c|}{$<28$} & \multicolumn{3}{|c|}{$>32$} \\
\hline & Mean & s.e. & No. & Mean & s.e. & No. \\
\hline \multicolumn{7}{|c|}{ Inseminations per conception } \\
\hline Heifers & 1.69 & $1 \cdot 33$ & 29 & $2 \cdot 14$ & $1 \cdot 81$ & 35 \\
\hline Cows & 1.97 & 1.06 & 33 & $2 \cdot 37$ & 1.52 & 64 \\
\hline \multicolumn{7}{|l|}{ Pregnancy rate $(\%)$} \\
\hline \multicolumn{7}{|l|}{ Heifers: } \\
\hline $1-3$ inseminations & 89.6 & & 28 & $77 \cdot 9$ & & 27 \\
\hline$>4$ inseminations & $10 \cdot 4$ & & 3 & $22 \cdot 1$ & & 8 \\
\hline \multicolumn{7}{|l|}{ Cows: } \\
\hline $1-3$ inseminations & $91 \cdot 4$ & & 30 & $75 \cdot 6$ & & 46 \\
\hline$>4$ inseminations & 8.6 & & 3 & $24 \cdot 4$ & & 5 \\
\hline
\end{tabular}

inseminations per conception tended to be higher and pregnancy rate tended to be lower in the HP cows compared with the LP cows in both herds (Table 2).

The reproductive performance of the HP cows in herds III and IV, as in herds I and II, tended to be lower compared with the LP cows (Table 3). However due to the small number of cows, no statistically significant differences could be shown.

\section{Conclusions}

It seems that HP cows utilize a greater amount of the available protein pool for milk protein production than LP cows. As a result, a shortage of available protein for other needs, may arise. The lower blood urea level of the HP cows compared with the LP cows, supports this possibility. Accordingly, if the protein requirement of the HP cows is higher, it means that the selection of cows for high milk protein concentration will require a revision of the present protein recomendations.

\section{References}

Ezra, E., Raz, A. and Weller, Y. 1988. Milk protein and fat in the Israeli dairy herd. A report submitted to the Dairy Cattle Association, Israel.

Oldham, J. D., Simm, G. and Marsden, S. 1992. Nutritiongenotype interaction in dairy cattle. In Recent advances in animal nutrition - 1992 (ed. P. C. Garnsworthy, W. Haresign and D. J. A. Cole), pp. 73-92. Butterworths, London. 